О.В. Турінський, Б.О. Демідов, Д.А. Гриб, О.О. Хмелевська

Харківський начіональний університет Повітряних Сил ім. I. Кожедуба, Харків

\title{
МЕТОДИЧНІ АСПЕКТИ ПЛАНУВАННЯ РОЗВИТКУ СИСТЕМ ОЗБРОЄННЯ ПРОТИПОВІТРЯНОЇ ОБОРОНИ В УМОВАХ РЕСУРСНОГО ОБМЕЖЕННЯ
}

У статті виділяються аспекти і положення підготовки і реалізації планів і програм розвитку складних систем військового призначення. Значна увага приділена напрямку визначення шляхів заощадження ресурсів для створення нових систем багатовартісних зразків озброєння і військової техніки.

У статті виділяються деякі положення з позитивного досвіду, які б могли бути результативно застосованими у практиці підготовки і реалізації планів і програм розвитку системи озброєння протиповітряної оборони держави з урахуванням специфічних особливостей існуючих обмежень різного характеру, у тому числі організаційних і фінансових.

Перспективна багатопозиційна система протиповітряної оборони має включати до себе новітні вогневі засоби, засоби розвідки, управління і забезпечення з бережливими їх життєвими циклами, а система озброєнь протиповітряної оборони у иілому має мати свій бережливий керований життєвий ијикл. Реалізація планів і програм розвитку має бути зорієнтована на виконання циих вимог.

Концепчиія розвитку системи озброєння протиповітряної оборони має у системній єдності відображувати оперативно-стратегічні й оперативно-тактичні потреби, науково-технічні можливості $i$ воєнноекономічну доцільність реалізащії запланованих напрямків вдосконалення і розвитку системи озброєння у програмному періоді часу.

Розробка і виробництво нових і вдосконалення існуючих зразків ОВТ має декілька їх варіантів реалізаичї, а саме - иче революичійний і еволюччійний варіанти і глибокої, середньої і незначної модернізації.

Ключові слова: плани і програми розвитку системи військового призначення, бережливий життєвий ичкл, ресурсні обмеження.

\section{Вступ}

Постановка проблеми. У відомих публікаціях [1-2] та інших розглядаються методичні підходи до формування обліку перспективної системи озброєння 3С держави. Виділяються аспекти формування програм і планів розвитку системи озброєння та узгодження заходів на плановий період іiі розвитку, з урахуванням початкових умов (стану) планування. Окремо у наукових працях розглядається питання формування бюджету розвитку окремих складових системи озброєння ЗС держави [3-4]. Разом з цим недостатньо уваги приділено плануванню розвитку високотехнологічних систем озброєння видів 3С держави, якою є система озброєння протиповітряної оборони.

Підтримання відповідної системи озброєння ППО у необхідній якості і подальше ії̈ вдосконалення потребує виконання комплексу заходів і робіт організаційного, координаційного, методичного, науково-технічного і виробничо-технологічного характеру, які, перш за все, мають бути зорієнтовані на: визначення стану системи і очікуваних умов іiі застосування; уточнення концепції розвитку і задач перспективної системи озброєння ППО, їі обліку, у тому числі оперативно-стратегічних і оперативнотактичних вимог, що висуваються до неї і до ії структурних компонентів; формування основних таких положень, до включення їх у проекти планів і програми розвитку системи озброєння, які були б підтримані реальним фінансуванням і іншими ресурсами держави у плановому періоді часу при забезпеченні очікуваного рівня ризику; формування стійкої кооперації виконавців робіт 3 координацією їх дії в умовах зміни ситуації в оборонно-промисловому комплексі (ОПК) і тощо.

Значні вартість СОППО і фінансові обмеження будь-якої держави у створенні такої системи озброєння, тривалий період реалізації програм розвитку СОППО, а також неможливість змінити вектор іiі розвитку на протязі короткострокового періоду планування вимагають використання науково обгрунтованого і апробованого методичного апарату панування процесу розвитку.

Для України існує актуальне наукове завдання розробки науково-медичного апарату обгрунтування пропозицій до планів розвитку систем озброєння, у тому числі і протиповітряної оборони в умовах ресурсних обмежень. 
Аналіз останніх досягнень і публікацій. Система озброєння протиповітряної оборони держави і іiі 3С (СОППО) як складна автоматизована система військового призначення $є$ сукупністю бойових засобів, засобів бойового управління і забезпечення, що розподілені у організаційно штатних формуваннях протиповітряної оборони (ППО) у відповідності з їх функціональним призначенням, організаційно об'єднаних в межах угруповань протиповітряної оборони, що забезпечують оборону і захист (прикриття) об'єктів інфраструктури держави і військ (сил) від ударів засобів повітряного нападу при виконанні бойових завдань в операціях (бойових діях) і в умовах мирного часу [1]. Вона включає такі основні підсистеми, як: розвідувально-інформаційна; ураження і подавлення засобів повітряного нападу і їх систем забезпечення; управління веденням протиповітряної оборони у цілому і їі засобами; забезпечення засобами бойового, матеріального, технічного і тилового призначення. СОППО функціонує в межах угруповань військ (сил) ППО, є ії матеріально-технічною основою, що складається 3 новітніх та інших вогневих засобів, засобів розвідки повітряного простору, а також засобів автоматизованого управління і забезпечення ведення бойових дій. Для виконання широкого кола завдань СОППО має забезпечувати введення ефективної боротьби з усіма типами ЗПН, що діють по об'єктам і військам, що прикриваються. Основу змісту боротьби 3 повітряним противником будь-якого масштабу складають задачі, що вирішуються військами (силами) ППО і способи їх вирішення, що підтримується засобами ППО [5-14].

У найближчій перспективі вогневі засоби ППО мають забезпечувати боротьбу з засобами повітряного нападу (ЗПН) широкого спектру: балістичними ракетами оперативно-тактичного і тактичного призначення; крилатими ракетами, у тому числі, і гіперзвуковими; літаками дальнього радіолокаційного виявлення i управління; розвідувально-ударними комплексами; літаками розвідниками і постановниками завад; літаками стратегічної, тактичної і армійської авіації; вертольотами різного призначення; елементами високоточного озброєння; безпілотними літальними апаратами і іншими ЗПН, які з'являться у ближчий і віддаленій перспективах [5; 9-12].

Динамічний і широкомасштабний розвиток різноманітних ЗПН у провідних (промислово розвинутих) країнах, суттєве зростання їх ролі у досягненні перемоги над противником з нанесенням ефективних ударів 3 повітря та 3 найближчого космосу по різних об'єктах угрупованнях військ (сил) сторін протистояння обумовлюють необхідність невідкладного перегляду підходів в бік будівництва (реформування) системи ППО держави і їі ЗС, застосування сучасних засобів боротьби з повітряним противником. Це, в свою чергу, потребує реформування системи ППО у цілому і подальшого вдосконалення методології обгрунтування планів створення новітніх зразків ОВТ і формування програми розвитку іiі системи озброєння не тільки у найближчій, але і дещо віддаленій перспективі $[1 ; 3 ; 11-12 ; 15-16]$.

Для забезпечення узгодженого планування розвитку військ (сил) і їх систем озброєння необхідно забезпечити формування єдиних підходів до визначення часу, обсягу робіт, реалізованості запланованих заходів за плановий період, ризиків невиконання окремих заходів і програм розвитку у цілому в умовах ресурсних і фінансових обмежень.

Мета статті: сформувати доцільні і прийнятні методичні підходи розробки планів і програм розвитку системи озброєння ППО держави i iï 3С (СОППО) у плановому періоді з урахуванням наявних і очікуваних ресурсних обмежень.

\section{Викладення основного матеріалу}

Для активізації виконання вказаних і інших заходів та робіт у вказаній області діяльності необхідні об'єктивні вихідні дані і адекватний науковометодичний апарат, зміст і стан можливостей якого до теперішнього часу ще не є достатньо теоретично обгрунтованим і практично апробованим для застосування при вирішенні задач планування і програмування розвитку озброєння і військової техніки (OBT) у сучасних умовах ускладнення технічного оснащення 3С держави і їх видів [1; 9; 13].

Для прикладу, науково методичний апарат має охоплювати весь цикл стратегічного планування розвитку СОППО й оперативного управління цим розвитком на протязі програмного періоду часу. Він має організаційно-методично i інформаційно підтримувати процес проведення досліджень воєнностратегічного, воєнно-технічного і воєнно-економічного характеру, дозволяти відпрацьовувати науково обгрунтовані і ресурсно забезпеченні управлінські рішення в області подальшого розвитку системи ППО в цілому і формування перспективного обліку iii системи озброєння для забезпечення стійкого функціонування системи ППО держави.

Організаційно-методичний підхід до вирішення задач технічного оснащення ЗС i їх структурних компонентів (видів 3С, родів військ і тощо) має реалізовуватись у відповідності з взаємо узгодженими діями або розроблюваними (регулярно оновлюваними) у державі законотворчими, правовими та нормативними документами воєнного будівництва, а також рядом інших документів, що пов'язані 3 оборонною проблематикою.

До основоположних програмних i планових документів відносяться державні цільові програми і ДОЗ, на основі яких здійснюється виконання заходів і робіт з розвитку ОВТ, у тому числі і розвитку засобів ППО. 
ДЦПО це довгостроковий плановий документ, що має взаємопов'язаний за цілями, ресурсами і термінами здійснення комплексу робіт і заходів з розробки (модернізації), виробництва, капітального ремонту і підтримання у боєздатному стані зразків (комплексів, систем) ОВТ, що забезпечують вирішення завдань збройними силами і іншими військовими формуваннями у відповідності з їх призначенням.

Основним інструментом управління розвитком ОВТ і реалізації ДЦПО є державне оборонне замовлення (ДОЗ), що відноситься до документу короткострокового планування розвитку ОВТ. На його основі забезпечується реальне технічне оснащення 3С OBT і воєнно-технічним майном, підтримання ОВТ у боєздатному (працездатному) стані.

Головна мета ДОЗ - це задоволення поточних потреб 3С (їх видів і родів військ) і забезпечення розвитку їх системи озброєння, максимального на- ближення до відповідних показників ДЦПО з урахуванням ситуаційних змін поточних пріоритетів у розвитку ОВТ.

Комплекс заходів 3 формування і реалізації ДОЗ може бути зведений до розробки, затвердження і виконання: державного бюджету в частині витрат на національну оборону; основних показників і параметрів ДОЗ; власне ДОЗ.

Державне оборонне замовлення після взаємоузгодження включених до нього пропозицій підлягає затвердженню у встановленому порядку. Воно формується у відповідності з принципами системного підходу i комплексного цільового планування у певній послідовності (рис. 1) і вирішенні сукупності наукових задач, що представлені на рис. 2. Запропонована схема на виконання процедур оцінювання реалізованості заходів ДОЗ і розробки рекомендацій зії підвищення приведена на рис. 3.

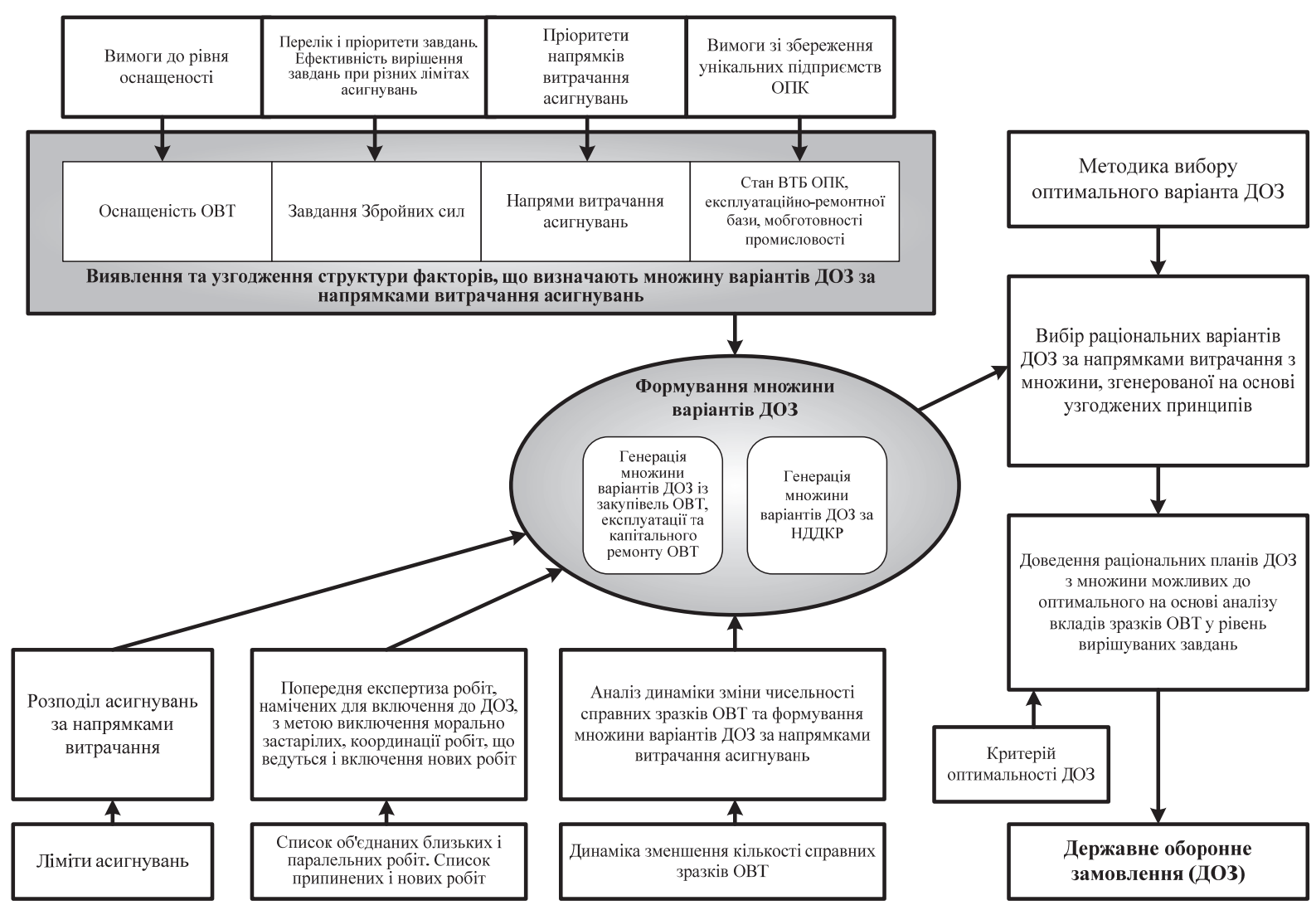

Рис. 1. Послідовність формування раціонального (оптимального) варіанту ДОЗ

В області планування розвитку ОВТ, формування і виконання відповідних цільових програм накопичений певний досвід (у міжнародному і національному масштабах) та відпрацьовані положення (стандарти), які доцільно враховувати і якими можливо керуватись на сучасному етапі державного воєнного будівництва при виконанні комплексу заходів з роз- робки (модернізації), виробництва, закупівлі і капітального ремонту ОВТ, з технічним оснащенням (переоснащення) 3С держави у цілому.

Нижче подається у систематизованому вигляді ряд узагальнених положень, які можуть бути використані у ближчий і дещо віддаленій перспективах (можливо, при деякому їх коригуванні і узгоджені 3 


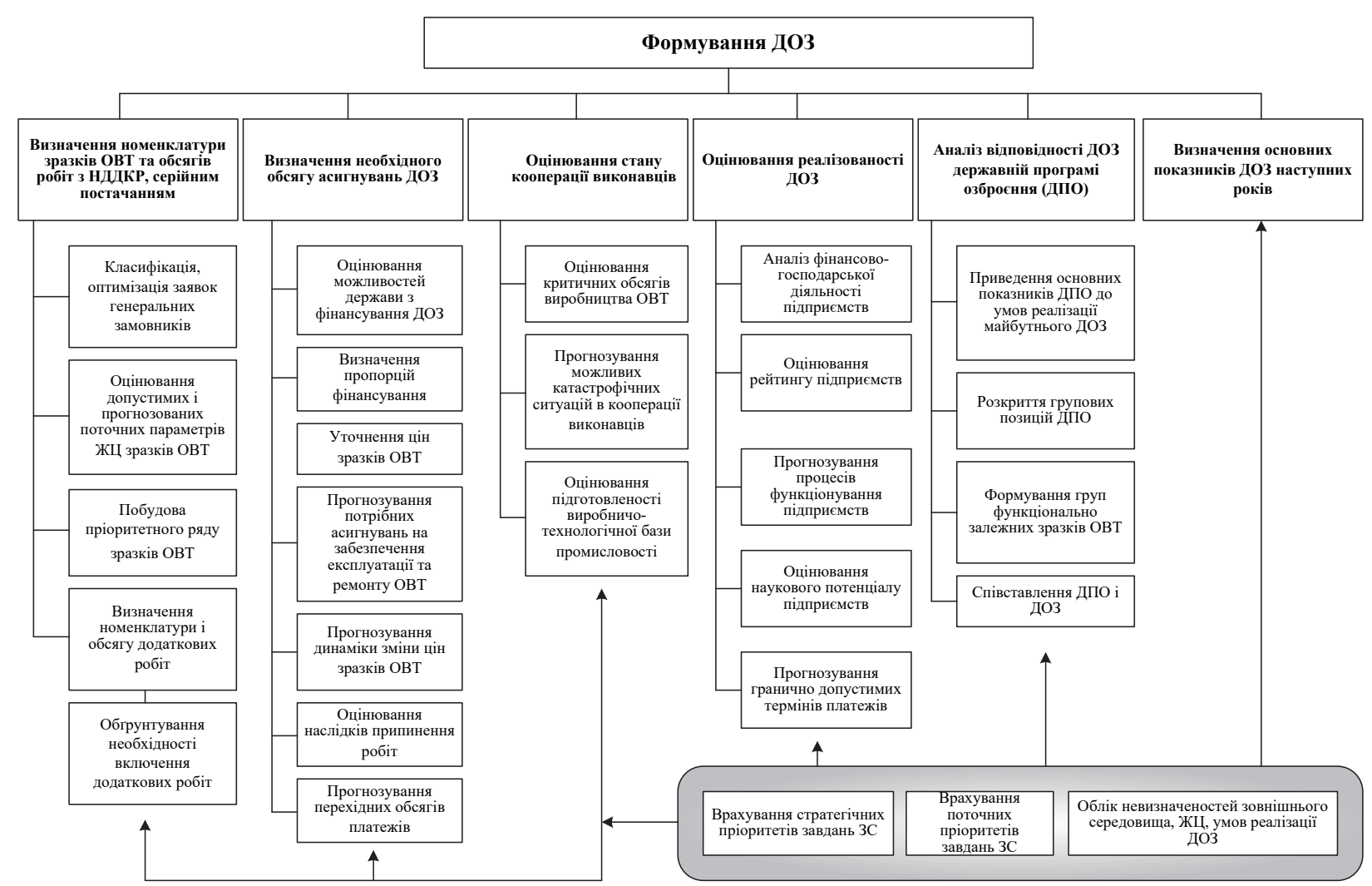

Рис. 2. Комплекс наукових завдань, що вирішуються при формуванні ДОЗ

очікуваними тенденціями розвитку ЗПН, формами, способами і засобами боротьби з повітряним противником) на систему озброєння ППО, що є одним з основних компонентів системи озброєння 3С держави.

При цьому концепція розвитку СОППО має у системній єдності відображувати оперативностратегічні й оперативно-тактичні потреби, науковотехнічні можливості і воєнно-економічну доцільність реалізації запланованих напрямків вдосконалення і розвитку системи озброєння у програмному періоді часу.

Облік СОППО, їі характеристики і параметри мають бути узгодженими з задачами що покладені на систему ППО держави і іï 3С.

Потрібна система озброєння ППО має бути основою для визначення основних напрямків розвитку засобів ППО і формування пропозицій до проекту державної цільової програми у частині розвитку зразків (комплексів систем) ОВТ ППО.

Початковим положенням у процесі зміни стану СОППО у плановому періоді часу має бути існуючий стан ОВТ ППО у військах (силах), а кінцевим потрібний стан, що відповідне обліку перспективної системи озброєння, що сформований у відповідності 3 досягнутими результатами науково-технічного прогресу у воєнно-технічні області інноваційного характеру і нагальними потребами військ (сил) ППО у оновленій системі озброєння.

До базових параметрів, що відображають стан СОППО, можуть бути віднесені номенклатура (види і типи), кількісний склад нових (модернізованих) i боєздатних (з прийнятними запасом технічного ресурсу і термінами служби існуючих справних зразків ОВТ ППО, що отримані від попередніх поколінь.

Стратегічною метою управління процесом розвитку ОВТ ППО $є$ забезпечення відповідності СОППО:

задачам і структурі системи ППО держави і ї̈ 3С; способам і формам боротьби з повітряним противником;

можливостям бюджетного фінансування витрат на розвиток СОППО.

Засоби повітряного (повітряно-космічного нападу у останній період часу (кінець XX початок XXI століття) отримали суттєвий розвиток у провідних країнах світу у частині розширення різноманіття їх видів і типів, тактико-технічних характеристик (бойових можливостей), втілення зразків ОВТ, що використовують новітні принципи дії, що реалізовані на основі останніх інноваційних досягнень науковотехнічного і технологічного прогресу. 


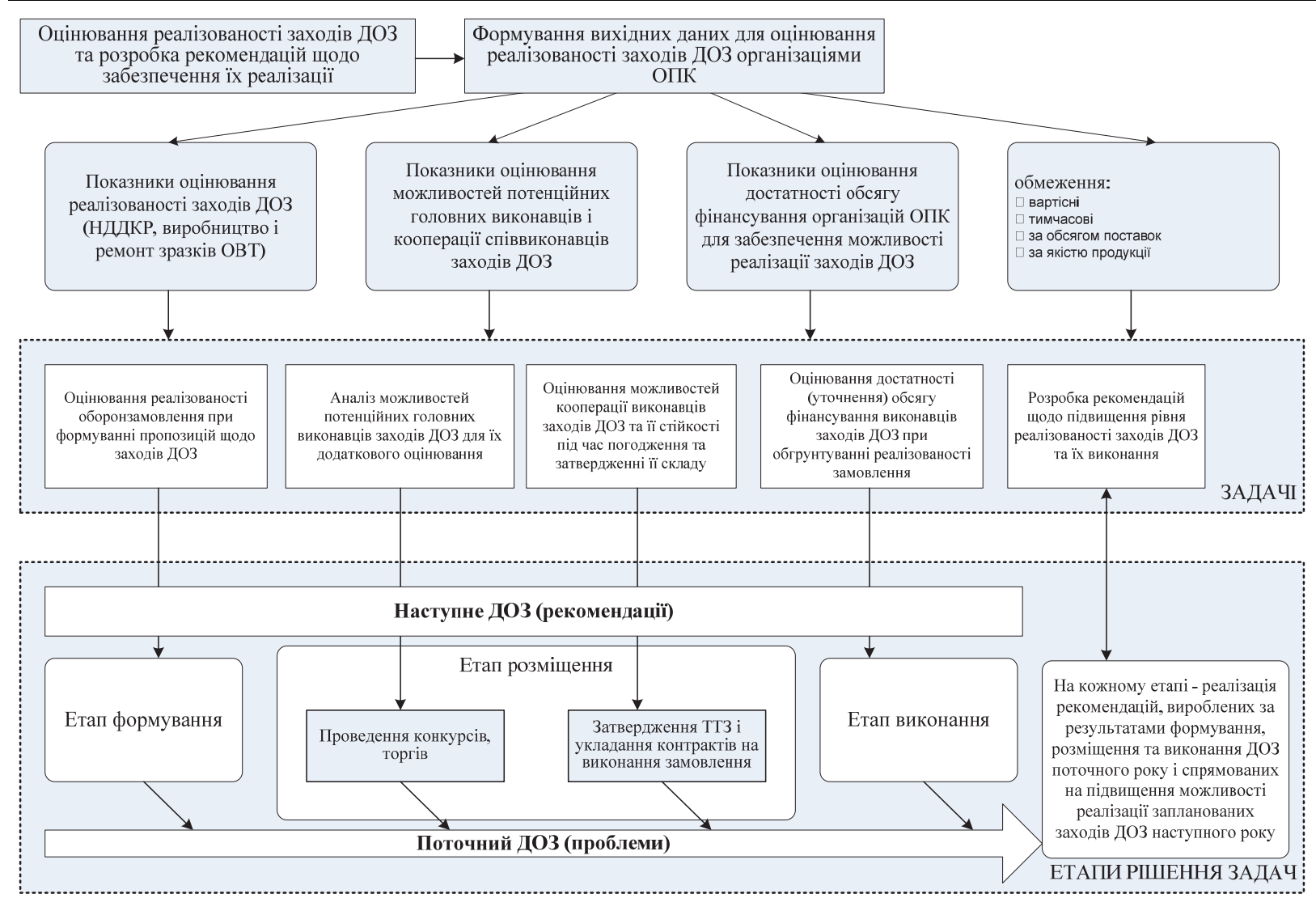

Рис. 3. Схема процедур оцінювання реалізованості заходів ДОЗ та розробки рекомендацій щодо підвищення ії рівня

Особливо це проявилось у ряді найбільш розвинутих країн світу, що прагнуть до оновлення технічного стану своїх ЗС на національному і міждержавному рівнях 3 широким використанням інтеграційних процесів організаційного, технічного і технологічного характеру, а також тенденцій раціонального витрачання ресурсів різних видів, у тому числі і фінансових [14; 17-19].

Прагнення досягти достатньо ефективного рівня протидії повітряному противнику входить до ряду важливих проблем воєнної безпеки держави і обумовлює проблему подальшого розвитку системи ППО, як складної автоматизованої системи військового призначення.

Нижче наводиться огляд досвіду підготовки і реалізації планів і програм розвитку складних систем військового призначення з урахуванням ресурсних обмежень.

У процесі розробки планів і програм розвитку продукції військового призначення (ПВП) як сукупності ОВТ і науково-технічної продукції, що створена при виконанні науково-дослідних робіт, порівнюються різні варіанти розвитку ПВП, що відрізняються між собою не тільки тактико-технічними характеристиками (ТТХ), але й значеннями основних техніко-економічних показників (ТЕП) програ- мних робіт і заходів (науково-дослідних робіт, закупівлі, капітального ремонту). До таких показників відносяться тривалість розробки і закупівлі ПВП, обсяг закупівлі (ремонту) і очікувані конкретні ціни на реалізацію окремих робіт і заходів, а також повні витрати, що характеризують витрати фінансових ресурсів на протязі усього життєвого циклу ПВП, у тому числі і на іiі утилізацію. Далі зміст наданих вище положень розкривається на прикладі ОВТ.

Створення (розробка і виробництво) нового i вдосконалення існуючих зразків ОВТ можуть здійснюватися у декількох варіантах: два варіанти повномасштабної розробки нового зразка (революційний і еволюційний) і три варіанти модернізації існуючого зразками (глибока, середня і незначна) [12-13; 16].

Революційний варіант розробки (виробництва) зразка нового покоління - варіант, при здійсненні якого відбуваються такі зміни конструктивних (технічних) рішень перспективного зразка по відношенню до аналогічного (однотипного зразка), у результаті яких реалізується сукупність науково-технічних нововведень інноваційного характеру, що пов'язані 3 наданням їм принципово нових властивостей (можливостей).

Еволюційний варіант розробки (виробництва) зразка нового покоління відрізняється від револю- 
ційного в основному тим, що зміни конструктивних рішень перспективного зразка не пов'язані з наданням йому принципово нових властивостей (можливостей), не призводять до суттєвого покращення усіх його характеристик.

Під глибокою модернізацією зразка розуміється заміна значної частини основних підсистем зразка на підсистеми нового покоління, у яких реалізується сукупність науково-технічних нововведень, що призводять до суттєвого покращення його характеристик.

За середньою модернізацією зразка розуміється заміна окремих підсистем зразка на підсистеми нового покоління, у яких реалізується сукупність науковотехнічних нововведень, що призводять до покращення характеристик. Вона займає проміжне положення між глибокою і незначною модернізацією.

За незначною модернізацією зразка розуміється доробка окремих підсистем, що призводить до незначного покращення його характеристик. У практиці програмно-цільового планування і реалізації програм розвитку ОВТ у ряді країн для оцінювання технічної оснащеності військ (сил) використовуються такі узагальнені категорії, як перспективний, новий, сучасний і застарілий зразок ОВТ.

При формуванні ознак і понять новий, сучасний і застарілий виріб ОВТ слід враховувати, що головними факторами, що об'єктивно обумовлюють потребу і темпи оновлення парків ОВТ ЗС будь-якої держави, є старіння ОВТ (моральне і фізичне) і необхідність підтримання певного рівня забезпечення воєнної безпеки (захисту життєво важливих інтересів) держави.

Новим вважається вперше створений або створений на заміну попереднього ефективний у застосуванні зразок ОВТ з більш кращими якісними показниками, який повністю задовольняє перспективним оперативно-тактичним вимогам (ОТВ) (з випередженням на 10-15 років), що не поступаються за тактико-технічними характеристиками (ТTX) перспективним зарубіжним аналогам і має значний запас технічного ресурсу і термінів служби.

Сучасним вважається зразок ОВТ, що повністю відповідає ОТВ і завданням 3С у ближчі 5-10 років, за показниками якості не поступається кращим світовим аналогам і має достатній запас технічного ресурсу і термінів служби.

Застарілим вважається зразок, що находить обмежене застосування, не відповідає сучасним ОТВ і завданням 3С, за якісними показниками значно поступається сучасним вітчизняним і світовим аналогам більш пізніх випусків і має незначний запас технічного ресурсу і термінів служби.

За основу оцінювання класифікації ОВТ за вказаними вище категоріями можуть бути прийняті наступні загальні положення: оцінювання має проводитись в межах одного типу ОВТ на основі загального показника якості зразка (комплексу) ОВТ, що обумовлює його здатність задовольняти потреби ЗС у певному періоді у відповідності з цільовим призначенням;

критерії, узагальнені показники якості і методи ï розрахунку для визначених категорій якості ОВТ мають бути узгодженими і порівняні з критеріями, показниками і методами оцінювання якості ОВТ, що використовуються у дослідженнях з обгрунтуванням перспектив розвитку ОВТ і грунтуватись на результатах цих оцінювань;

прогнозне оцінювання якості зразка ОВТ по критеріям новий, сучасний, застарілий має проводитись на часовому інтервалі з періодом випередження до 10-15 років, відповідно встановленому періоду довгострокового планування розвитку ОВТ.

Оцінювання має забезпечувати можливість однозначного віднесення до однієї з розглянутих категорій якості як окремого конкретного зразку ОВТ, що знаходиться в розробці, серійному виробництві або військах (силах), а також визначення співвідношення нових, сучасних і застарілих зразків у парку окремих видів і типів ОВТ, і їх порівняльної оцінки з парком аналогічних зразків ОВТ в провідних країнах.

Зразки ОВТ принципово нового покоління, що створюється на основі останніх досягнень науковотехнічного прогресу і новітніх технологій, що відповідають перспективним ОТВ, в основному будуть знаходитись на озброєнні однієї або декількох найбільш розвинених країн світу і доля їх у парку відповідного типу ОВТ буде незначною.

Озброєння останніх випусків (у тому числі після проведення модернізації), що найбільш повно задовольняють ОТВ та складають основу бойової могутності 3С, як за правило, складають 50...70\% парку існуючих основних видів ОВТ більшості розвинених у воєнному відношенні країн. Озброєння попередніх випусків складає основу бойової моці ЗС менш розвинутих у воєнно-технічному, технічному і економічному відношеннях країн.

При обгрунтуванні пропозицій у проекти довгострокових програм планових документів розвитку ОВТ доцільно спиратись на послідовний розгляд таких основних базових дослідницьких варіантів, як: потрібний, мінімально необхідний, критичний i збалансований варіанти розвитку [1; 12-13].

Потрібний варіант розвитку - це такий варіант, який спрямований на забезпечення паритету (якісного і кількісного) з угрупованнями 3С суміжних держав (у тому числі воєнних блоків) на одному з регіональних напрямків, для яких по завершенню програмного періоду прогнозується найбільший бойовий потенціал. Основна мета реалізації цього варіанту - досягнення готовності до вирішення повного обсягу задач у регіональній війні з технічно сильним противником. 
Мінімально необхідний варіант розвитку - це варіант, що спрямований на досягнення кількісноякісних параметрів системи озброєння у відповідності 3 вимогами законодавчих (планових) і нормативних документів, що діють (приймаються) до початку прогнозованого періоду часу (в рамках існуючого бойового складу 3С, або законодавчо затвердженого бойового складу у відповідності з перспективним обліком 3С).

Критичний (мінімально припустимий) варіант розвитку орієнтується на підтримання рівня вирішення основних стратегічних завдань $3 \mathrm{C}$ i задач, характерних для воєнних дій рівня збройного конфлікту, а саме: підтримання бойового потенціалу угруповання військ, що забезпечується на мінімально допустимому рівні вирішення основної задачі ЗС у збройному конфлікті (локалізацією), i, по можливості, найбільш повної відповідності системі нормативноправових документів, що діють (прийняті до початку програмного періоду). Основна мета реалізації цього варіанту $є$ у досягненні готовності до вирішення задач в одному-двох збройних конфліктах.

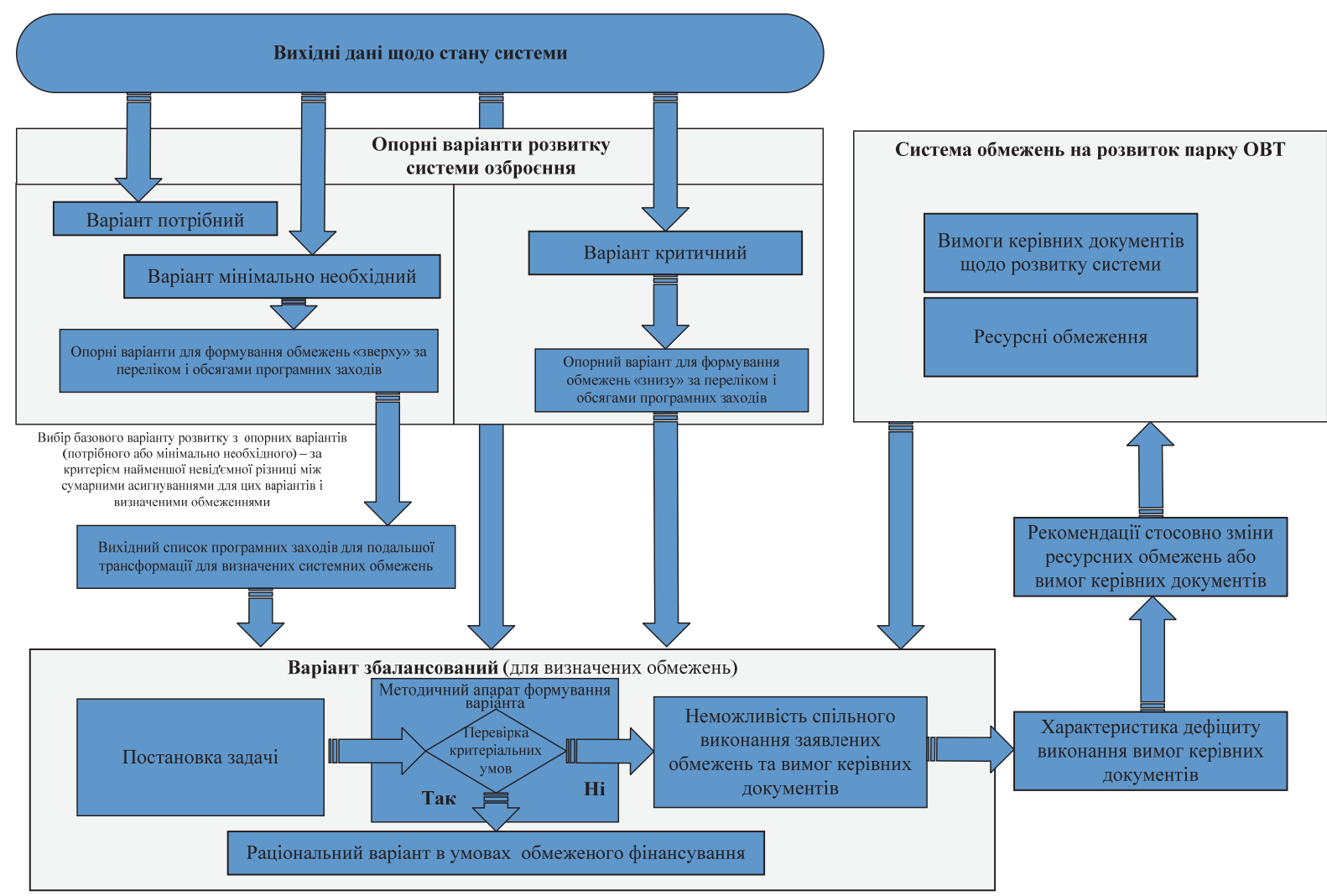

Рис. 4. Загальна схема обгрунтування програмних заходів розвитку системи озброєння в умовах обмежень

Потрібний, мінімально необхідний і критичний варіанти розвитку можуть розглядатись як опорні варіанти (рис. 4).

Збалансований варіант розвитку при обмеженому фінансуванні (що розглядається як компромісний) орієнтується на досягнення максимально можливого бойового потенціалу угруповання ЗС при визначених фінансових обмеженнях i, по можливості, на найбільш повну відповідність системі керівних нормативних правових документів, що діють (прийняті) до початку програмного періоду часу. Основна мета реалізації варіанту - мінімізація дефіциту рівня вирішення задач ЗС відносно визначених для вихідного опорного варіанту потреб, при наявності ліміту з фінансування.

В умовах обмеженого фінансування обгрунтування пропозицій до програмно-планових докумен- тів розвитку системи озброєння може бути реалізованим у вигляді послідовного виконання таких етапів, як:

вибір у якості базового варіанту для наступного формування проекту програми озброєння одного 3 вказаних вище опорних варіантів розвитку системи озброєння (може бути здійснений у відповідності 3 умовою найменшої відмінності між сумарним асигнуванням для цих варіантів і призначеним обмеженням (рис. 4).

проведення оптимізації вибраного базового варіанту розвитку системи озброєння, що виходить із заданого фінансового обмеження (на основі оптимізаційних методів);

проведення комплексного техніко-економічного оцінювання сформованого варіанту (у тому числі перевірки критеріальних умов); 
відпрацювання рекомендацій 3 коригування ресурсних обмежень (в бік збільшення) або вимог керівних документів (щодо їх часткового зниження по рівню вирішення задач, по директивним кількісним параметрам переоснащення парку ОВТ і тощо), якщо виявляється неможливим виконання заявлених обмежень і вимог нормативних і правових документів (повернення до другого етапу із вказаною послідовністю).

При досягненні заданих обмежень і висунутих вимог (у тому числі, можливо скоригованих) буде сформованим збалансований і ресурсно припустимий варіант програмних заходів розвитку системи озброєння, який дозволяє уточнити розподілення лімітів фінансування по підсистемам системи озброєння і етапах життєвого циклу (для видових замовників), а також приріст у розвитку тих або інших видів озброєння з міжвидових позицій.

При постановці задачі оновлення збалансованого варіанту розвитку системи озброєння в умовах ресурсних і фінансових обмежень необхідно задавати [1; 9]:

множину програмних заходів, у якості якої використовується сукупність робіт одного з опорних варіантів розвитку системи озброєння з урахуванням умов найменшої різниці між сумарним асигнуванням для обраного варіанту і виділеним обсягом фінансування на програмний період (базовий варіант, рис. 4);

потрібні ресурси (асигнування) по кожному 3 заходів;

кількісно-якісні показники стану парку різних типів ОВТ;

вимоги основних правових документів в області будівництва 3С (їх видів) і пріоритетів розвитку ОВТ на перспективу.

Необхідно сформулювати необхідну і достатньо ресурсно припустиму множину програмних заходів, що забезпечують максимізацію цільової функції, характер якої залежить від цільових установок формування варіанту.

У якості умови оптимальності можуть бути використані такі можливі варіанти, як:

максимум бойового потенціалу угруповання військ;

максимум відносного підвищення ефективності (бойового потенціалу, рівня вирішення задач) угруповання військ у порівнянні з очікуваною при відсутності програмних заходів;

максимум функції узагальнених показників кількісно-якісного стану парку ОВТ (оснащеності, справності, частки сучасних зразків, коефіцієнт технічного рівня найкращих зразків у своєму типі OBT, підсистем ОВТ і тощо) у залежності від параметрів програмних заходів та інші;

додатково може використовуватись умова досягнення мінімуму експлуатаційних витрат і тощо.

\section{Висновки}

У якості основи підготовки і реалізації виконання планових програмних заходів програми розвитку СОППО у програмному періоді має виступати програмно-цільовий метод планування i методи ситуаційного управління.

Основним поточним (оперативним) інструментом управління виконання відповідної державної цільової програми у галузі ППО держави і їі ЗС має бути ДОЗ, що враховує зміни поточної динаміки у потребах зразків ОВТ ППО різних видів і типів.

Основою для прийняття рішень про включення заходів і робіт з створення зразків (комплексів, систем) ОВТ ППО у довгострокові або середньострокові плани організацій і підприємств промисловості, поряд з характеристиками їх якості, є вартісні показники.

Теоретичні і методичні основи оцінювання вартості зразків ОВТ ППО мають включати: систему принципів оцінювання вартості зразків (комплексів, систем) ОВТ ППО; пропозиції з врахування технікоекономічної доцільності реалізації заходів і робіт; комплекс методик оцінювання вартості наукових досліджень і дослідно-конструкторських робіт, виробництва і ремонту зразків ОВТ; методичний апарат оцінювання фінансових технологічних і технікоекономічних ризиків, при створенні ПВП; методичне забезпечення оцінювання взаємозв'язків часових показників і показників обсягу й вартості ПВП; методичні підходи до визначення точності оцінювання вартісних показників заходів і їх верифікація.

Досвід розвитку вітчизняного ОПК вказує на те, що система ціноутворення, що діє на ПВП у теперішній час, має витратний характер, а присутні їй недоліки негативно впливають на реалізацію планів створення зразків ОВТ ППО і їх якості. Необхідно переходити до раціональної цінової політики і бережливої цілеспрямованої реалізації дослідно-конструкторських робіт, серійного виробництва (у тому числі і до бережливої технологічної підготовки виробництва), експлуатації і у цілому життєвих циклів складних зразків (комплексів, систем) ОВТ ППО.

При постановці задачі оновлення збалансованого варіанту розвитку системи СОППО в умовах ресурсних і фінансових обмежень необхідно визначити множину програмних заходів 3 урахуванням умов найменшої різниці між сумарним асигнуванням для обраного варіанту і виділеним обсягом фінансування на програмний період, потрібні ресурси (асигнування) по кожному з заходів, кількісно-якісні показники стану парку різних типів ОВТ, вимоги основних правових документів в області будівництва 3С (їх видів) і пріоритетів розвитку ОВТ на перспективу. 
Одним з напрямків вдосконалення механізму планування розвитку багатовартісного і наукоємного озброєння є розробка і нормативне затвердження методик оцінювання вартості життєвого циклу зраз- ка ОВТ ці системи озброєння у цілому та готовності підприємств ОПК забезпечити створення (модернізацію) перспективних зразків у прогнозований період.

\section{Список літератури}

1. Системно-концептуальные основы методологии военно-научных исследований и решения прикладных военнотехнических проблем: монография / Б.А. Демидов, С.Н. Остапенко, М.И. Луханин, А.Ф. Величко. - Тверь: ЗНПАО, 2014. $-676 \mathrm{c}$.

2. Чепков І.Б. Деякі проблеми формування державної військово-технічної та оборонно-промислової політики України на сучасному етапі / І.Б. Чепков // Наука і оборона. - 2017. - № 3(4). - С. 45-53.

3. Методика нечіткого оцінювання для систем підтримки прийняття проектних рішень на етапах створення зразків озброєння і військової техніки / О.О. Гловін, М.В. Зірка, Н.П. Кадет, Н.М. Коцюруба // Озброєння та військова техніка. 2019. - № 3(23). - С. 99-109.

4. Методичні рекомендації щодо формування методології воєнно-економічного обгрунтування (супроводження) програм розвитку Збройних Сил України / О.М. Семененко, О.Г. Водчиць, Р.В. Бойко, Ю.Б. Добровольський, С.С. Масловський, О.А. Корочкін // Системи озброєння і військова техніка. - 2018. - № 2(54). - С. $142-150$. https://doi.org/10.30748/soivt.2018.54.20.

5. Алімпієв А.А. Довідник учасника АТО: озброєння і військова техніка Збройних Сил Російської Федерації / А.А. Алімпієв, Г.В. Пєвцов, Д.А. Гриб. - Х.: Оригінал, 2015. - 732 с.

6. Ерохин И.В. Воздушно-космическая сфера и вооруженная борьба в ней / И.В. Ерохин. - Тверь: Тверская обл. типография, 2008. -240 с.

7. Федосов Е.А. Авиация ПВО России и научно-технический прогресс: боевые космические комплексы и системы вчера, сегодня, завтра: монография / Е.А. Федосов. - М.: Дрофа, 2005. - 815 с.

8. Титаренко О.Б. Обгрунтування шляхів підвищення живучості системи зенітного ракетного прикриття при відбитті удару засобів повітряного нападу противника/О.Б. Титаренко, О.М. Місюра, А.В. Тристан // Системи озброєння і військова техніка. - 2014. - № 1(37). - С. 76-80.

9. Лященко В.П. Воздушно-космическая оборона государства: современный этап и перспективы развития / В.П. Лященко. - М.: Экономика, 2015. - 366 с.

10. Минаев В.Н. Диалектика технологий воздушно-космической обороны / В.Н. Минаев. - М.: Столичная энциклопедия, 2011. - 356 с.

11. Ярош С.П. Теоретичні основи побудови та застосування розвідувально-управляючих інформаційних систем протиповітряної оборони: монографія / С.П. Ярош. - Х.: ХУПС, 2012. - 512 с.

12. Методические основы системных исследований и решения проблем технического оснащения вооруженных сил государства: монография. Книга 1 / Б.А. Демидов, О.П. Коростылев, С.Н. Остапенко, Д.А. Гриб. - К.: Стилос, $2016 .-655$ с.

13. Буренок В.М. Методология обоснования перспектив развития средств вооруженной борьбы общего назначения / В.М. Буренок, А.В. Погребняк, А.М. Скотников. - М.: Машиностроение, 2010. -368 с.

14. Вооруженные силы зарубежных государств / А.Н. Сидорин, Г.М. Мингатин, В.М. Прищепов, В.П. Акуленко. М.: Воениздат, 2009. - 528 с.

15. Остапенко С.Н. Оценка научно-технической и производственно-технологической реализуемости проектов на стадиях жизненного цикла сложных технических систем: монография / С.Н. Остапенко. - Тверь: ЗНП АО “Отделение ПВЭ и Ф”, 2015. - 276 с.

16. Буренок В.М. Технологические и технические основы развития вооружения и военной техники / В.М. Буренок. М.: Граница, 2010. -216 с.

17. Козин В.П. Эволюция противоракетной обороны США и позиция России (1945-2013) / В.П. Козин. - М.: Российский Институт стратегических исследований, 2013. - 384 с.

18. Лященко В.П. Торговля оружием: проведение НИОКР, операции со стратегическими материалами и сырьём, риски и управление рисками / В.П. Лященко. - М.: Экономика, 2008. - 351 с.

19. Лященко В.П. Торговля оружием: последовательный сервис, запасные части, модернизации. - М.: Экономика, 2007. $-236 \mathrm{c}$.

\section{References}

1. Demydov, B.A., Ostapenko, S.N., Lukhanyn, M.Y. and Velychko, A.F. (2014), "Systemno-kontseptualnye osnovy metodolohyy voenno-nauchnykh yssledovanyi y reshenyia prykladnykh voenno-tekhnycheskykh problem" [System-conceptual foundations of the methodology of military scientific research and the solution of applied military-technical problems], ZNPAO, Tver, $676 \mathrm{p}$.

2. Chepkov, I.B. (2017), "Deiaki problemy formuvannia derzhavnoi viiskovo-tekhnichnoi ta oboronno-promyslovoi polityky Ukrainy na suchasnomu etapi” [Dealing problems and formulating the sovereign state-technical and defense-industrial policies of Ukraine at the current stage], Science and Defense, No. 3(4), pp. 45-53.

3. Hlovin, O.O., Zirka, M.V., Kadet, N.P. and Kotsiuruba, N.M. (2019), "Metodyka nechitkoho otsiniuvannia dlia system pidtrymky pryiniattia proektnykh rishen na etapakh stvorennia zrazkiv ozbroiennia i viiskovoi tekhniky" [Fuzzy evaluation methodology for systems of decision support of design decisions at the stages of creation of samples of arms and military equipment], Weapons and Military Equipment, No. 3(23), pp. 99-109.

4. Semenenko, O.M., Vodchyts, O.H., Boiko, R.V., Dobrovolskyi, Yu.B., Maslovskyi, S.S. and Korochkin, O.A. (2018), "Metodychni rekomendatsii shchodo formuvannia metodolohii voienno-ekonomichnoho obgruntuvannia (suprovodzhennia) prohram rozvytku Zbroinykh Syl Ukrainy" [Methodical recommendations for the formation of methodology military-economic substantiation (administration) of programs development of Armed Forces of Ukraine], Systems of Arms and Military Equipment, No. 2(54), pp. 142-150. https://doi.org/10.30748/soivt.2018.54.20. 
5. Alimpiiev, A.A., Pievtsov, H.V. and Hryb, D.A. (2015), "Dovidnyk uchasnyka ATO: ozbroiennia i viiskova tekhnika Zbroinykh Syl Rosiiskoi Federatsii" [ATO Participant's Handbook: Weapons and Military Equipment of the Armed Forces of the Russian Federation], Oryhinal, Kharkiv, 732 p.

6. Erokhyn, Y.V. (2008), "Vozdushno-kosmycheskaia sfera y vooruzhennaia borba $v$ nei" [The aerospace sphere and the armed struggle in it], Tverskaya obl. typohrafyia, Tver, $240 \mathrm{p}$.

7. Fedosov, E.A. (2005), "Avyatsyia PVO Rossyy y nauchno-tekhnycheskyi prohress: boevye kosmycheskye kompleky y systemy vchera, sehodnia, zavtra" [Russian air defense and scientific and technological progress: military space systems and systems yesterday, today, tomorrow], Drofa, Moscow, 815 p.

8. Tytarenko, O.B., Misiura, O.M. and Trystan, A.V. (2014), "Obgruntuvannia shliakhiv pidvyshchennia zhyvuchosti systemy zenitnoho raketnoho prykryttia pry vidbytti udaru zasobiv povitrianoho napadu protyvnyka" [Ground of ways of increase of vitality of system of zenithal rocket protection at reflection of blow of facilities of air attack of opponent], Systems of Arms and Military Equipment, No. 1(37), pp. 76-80.

9. Liashchenko, V.P. (2015), "Vozdushno-kosmycheskaia oborona hosudarstva: sovremennyi etap y perspektyvy razvytyia" [State Aerospace Defense: The Current Stage and Prospects for Development], Ekonomyka, Moscow, 366 p.

10. Mynaev, V.N. (2011), "Dyalektyka tekhnolohyi vozdushno-kosmycheskoi oborony" [Dialectics of aerospace defense technologies], Stolychnaia entsyklopedyia, Moscow, 356 p.

11. Yarosh, S.P. (2012), "Teoretychni osnovy pobudovy ta zastosuvannia rozviduvalno-upravliaiuchykh informatsiinykh system protypovitrianoi oborony" [Theoretical bases of construction and application of intelligence-control information systems of air defense], KNAFU, Kharkiv, $512 \mathrm{p}$.

12. Demydov, B.A., Korostylev, O.P., Ostapenko, S.N. and Hryb, D.A. (2016), "Metodycheskye osnovy systemnykh yssledovanyi y reshenyia problem tekhnycheskoho osnashchenyia vooruzhennykh syl hosudarstva" [Methodical basis of systematic research and solution of problems of technical equipment of the armed forces of the state], Stylos, Kyiv, $655 \mathrm{p}$.

13. Burenok, V.M., Pohrebniak, A.V. and Skotnykov, A.M. (2010), "Metodolohyia obosnovanyia perspektyv razvytyia sredstv vooruzhennoi borbbl obshcheho naznachenyia" [Methodology for substantiating the prospects for the development of general-purpose military weapons], Mashynostroenye, Moscow, 368 p.

14. Sydoryn, A.N., Mynhatyn, H.M., Pryshchepov, V.M. and Akulenko, V.P. (2009), "Vooruzhennye syly zarubezhnykh hosudarstv" [Armed Forces of Foreign States], Voenyzdat, Moscow, 528 p.

15. Ostapenko, S.N. (2015), "Otsenka nauchno-tekhnycheskoi y proyzvodstvenno-tekhnolohycheskoi realyzuemosty proektov na stadyiakh zhyznennoho tsykla slozhnykh tekhnycheskykh system" [Assessment of scientific, technical and production and technological feasibility of projects at the stages of the life cycle of complex technical systems], ZNP AO "Otdelenye PVE y F”, Tver, 276 p.

16. Burenok, V.M. (2010), "Tekhnolohycheskye y tekhnycheskye osnovy razvytyia vooruzhenyia y voennoi tekhnyky" [Technological and technical bases of development of arms and military equipment], Hranytsa, Moscow, $216 \mathrm{p}$.

17. Kozyn, V.P. (2013), "Evoliutsyia protyvoraketnoi oborony SShA y pozytsyia Rossyy (1945-2013)" [The Evolution of US Missile Defense and Russia's Position (1945-2013)], Rossyiskyi Ynstytut stratehycheskykh yssledovanyi, Moscow, 384 p.

18. Liashchenko, V.P. (2008), "Torhovlia oruzhyem: provedenye NYOKR, operatsyy so stratehycheskymy materyalamy y syrjom, rysky y upravlenye ryskamy" [Arms trade: $R \& D$, strategic materials and raw materials operations, risks and risk management], Ekonomyka, Moscow, 351 p.

19. Liashchenko, V.P. (2007), "Torhovlia oruzhyem: posledovatelnyi servys, zapasnye chasty, modernyzatsyy" [Arms trade: consistent service, spare parts, upgrades], Ekonomyka, Moscow, 236 p.

\section{Bidомості про авторів:}

\section{Турінський Олександр Васильович}

кандидат технічних наук

начальник Харківського національного університету

Повітряних Сил ім. І. Кожедуба,

Харків, Україна

https://orcid.org/0000-0001-6888-6045

\section{Демідов Борис Олексійович}

доктор технічних наук професор

провідний науковий співробітник Харківського національного університету Повітряних Сил

ім. І. Кожедуба,

Харків, Україна

https://orcid.org/0000-0003-1728-6925

\section{Гриб Дмитро Анатолійович}

кандидат військових наук доцент

головний науковий співробітник Харківського національного університету Повітряних Сил

ім. І. Кожедуба,

Харків, Україна

https://orcid.org/0000-0001-8478-978X

\section{Information about the authors:}

\section{Oleksandr Turinskyi}

Candidate of Technical Sciences

Chief of Ivan Kozhedub Kharkiv

National Air Force University,

Kharkiv, Ukraine

https://orcid.org/0000-0001-6888-6045

\section{Borys Demidov}

Doctor of Technical Sciences

Professor

Lead Research of Ivan Kozhedub

Kharkiv National Air Force University, Kharkiv, Ukraine

https://orcid.org/0000-0003-1728-6925

\section{Dmitry Grib}

Candidate of Military Sciences

Associate Professor

Chief Research of Ivan Kozhedub

Kharkiv National Air Force University,

Kharkiv, Ukraine

https://orcid.org/0000-0001-8478-978X 
Хмелевська Ольга Олександрівна

кандидат технічних наук

старший науковий співробітник

провідний науковий співробітник Харківського

національного університету

Повітряних Сил ім. І. Кожедуба,

Харків, Україна

https://orcid.org/0000-0001-9018-5552
Olga Khmelevska

Candidate of Technical Sciences

Senior Research

Lead Research

of Ivan Kozhedub

Kharkiv National Air Force University,

Kharkiv, Ukraine

https://orcid.org/0000-0001-9018-5552

\title{
МЕТОДИЧЕСКИЕ АСПЕКТЫ ПЛАНИРОВАНИЯ РАЗВИТИЯ СИСТЕМ ВООРУЖЕНИЯ ПРОТИВОВОЗДУШНОЙ ОБОРОНЫ В УСЛОВИЯХ РЕСУРСНЫХ ОГРАНИЧЕНИЙ
}

\author{
А.В. Туринский, Б.А. Демидов, Д.А. Гриб, О.А. Хмелевская
}

В статье выделяются аспекты и положения подготовки и реализации планов и программ развития сложных систем военного назначения. Значительное внимание уделено направлению определения путей сбережения ресурсов для создания новых дорогостоящих образцов вооружения и военной техники.

В статье выделяются некоторые положения из положительного опыта, которые могли бы быть результативно применены в практике подготовки и реализации планов и программ развития системы вооружения противовоздушной обороны государства с учетом специфических особенностей существующцих ограничений различного характера, в том числе организационных и финансовых.

Перспективная многопозиционная система противовоздушной обороны долюна включать в себя новейшие огневые средства, средства разведки, управления и обеспечения с бережливыми их жизненными ииклами, а система вооружений противовоздушной обороны в цуелом имеет свой бережливый управляемый жизненный циикл. Реализация планов и программ развития должна быть ориентирована на выполнение этих требований.

Концеепция развития системы вооружения противовоздушной обороны должна в системном единстве отображать оперативно-стратегические и оперативно-тактические потребности, научно-технические возможности и военно-экономическую целесообразность реализации запланированных направлений совершенствования и развития системы вооружения в программном периоде времени.

Разработка и производство новых современных образиов вворужения и военной техники имеет несколько вариантов реализации, а именно - это революционный и эволюцчонный варианты и глубокой, средней и незначительной модернизачии

Ключевые слова: планы и программы развития системы военного назначения, бережливый жизненный ияикл, ресурсные ограничения.

\section{METHODICAL ASPECTS OF PLANNING DEVELOPMENT OF ARMY SYSTEMS IN ARMS OF RESOURCE LIMITATION}

\author{
O. Turinskyi, B. Demidov, D. Grib, O. Khmelevska
}

The article highlights aspects and provisions for the preparation and implementation of plans and programs for the development of complex military systems. Much attention is paid to identifying ways to save resources to create new multi-value weapons and military equipment.

The article highlights some of the provisions of positive experience that could be effectively applied in the preparation and implementation of plans and programs for the development of the country's air defense weapons system, taking into account the specific features of existing restrictions of various nature, including organizational and financial.

A promising multi-position air defense system should include the latest firearms, reconnaissance, command, and deployment cycles, and the air defense armament system as a whole must have a thrifty guided life cycle. The implementation of development plans and programs should be oriented towards meeting these requirements.

The concept of the development of air defense systems should in systematic unity reflect operational-strategic and operational-tactical needs, scientific and technical capabilities and military-economic feasibility of implementing the planned areas of improvement and development of the weapons system in the programming period of time.

The composition of the scientific and methodological apparatus for estimating the value of weapons and military equipment samples is presented, namely: the system of principles for evaluating the value of samples (complexes, systems) of weapons and military equipment; proposals to take into account the feasibility of implementing measures and works; a set of methods for evaluating the cost of research and development, production and repair of weapons and military equipment; a methodological apparatus for assessing financial technological and technical and economic risks when creating military products; methodological support of estimation of interrelation of time indicators and indicators of volume and cost of military production; methodological approaches to determining the accuracy of the measurement of the cost indicators of the measures and their verification.

The development and production of new and refinement of existing models of OVT has several variants of implementation, namely, it is a revolutionary and evolutionary variant and a deep, medium and minor modernization.

Keywords: military system development plans and programs, lean life cycle, resource constraints. 